\title{
STUDI LITERATUR: ANALISIS TEORI KONTEMPORER AKUNTANSI PERBANKAN SYARIAH
}

\author{
Nur Ika Mauliyah \\ Institut Agama Islam Negeri (IAIN) Jember \\ Email: nurikamauliyah@gmail.com
}

\begin{abstract}
This research is a literature study that discusses Islamic banking accounting theory analysis. Islamic banking accounting at this time is an action taken when conventional accounting does not fulfill the wishes of some Indonesian people who are Muslim. The offer provided by the Islamic economy is the best choice because banks have so far only wanted the maximum possible profit but lacked a humanist side to their customers. Products provided by Islamic banking such as mudharabah, musyarakah, wadi'ah, ijarah, wakalah, and so on. Sharia accounting reporting must uphold Islamic values in accordance with Islamic provisions so that there is no element of fraud in it. The accounting stage has an impact on management, owners, employees, and customers. Islamic accounting practice wants to implement a business environment that instills religious elements such as theological, humanist, and transcendental.
\end{abstract}

Keywords: Accounting, Islamic Banking

\begin{abstract}
Abstrak
Penelitian ini merupakan studi litelatur yang membahas analisis teori akuntansi perbankan syariah. Akuntansi perbankan syariah pada zaman ini merupakan tindakan yang diambil disaat akuntansi konvensional tidak memenuhi keinginan sebagian masyarakat Indonesia yang beragama Islam. Penawaran yang diberikan oleh ekonomi Islam merupakan pilihan terbaik karena perbankan selama ini hanya menginginkan keuntungan semaksimal mungkin tapi kekurangan sisi humanis kepada para nasabah. Produk-produk yang diberikan oleh perbankan syariah seperti mudharabah, musyarakah, wadi'ah, ijarah, wakalah, dan lain sebagainya. Pelaporan akuntansi syariahpun harus menjunjung nilai-nilai syariah sesuai dengan ketentuan Islam sehingga tidak ada unsur penipuan di dalamnya. Tahapan akuntansi memberi dampak terhadap manajemen, pemilik, pegawai, dan juga nasabah. Praktik akuntansi syariah ingin menerapkan lingkungan bisnis yang menanamkan unsur-unsur agama seperti teologis, humanis, dan transendental.
\end{abstract}

Kata Kunci: $\quad$ Akuntansi, Perbankan Syariah 


\section{6 | Nur Ika Mauliyah, STUDI LITERATUR: ANALISIS TEORI KONTEMPORER AKUNTANSI ....}

\section{Dasar Pemikiran}

Penawaran yang dilakukan melalui ekonomi Islam memiliki pemahaman yang ilmiah dan juga koheren yang tetap bisa diterapkan sesuai zaman. Peranan akuntansi perbankan syariah memiliki efek yang saat ini dapat dirasakan bagi nasabah yang menggunakan produk perbankan syariah. Dalam praktiknya akuntasi perbankan syariah mampu menerapkan akuntasi yang umum digunakan dalam perbankan konvensional yang membedakannya hanyalah adanya unsur-unsur syariah saat klasifikasi, peringkasan, pelaporan, analisa, transaksi dan hal-hal yang berhubungan dengan keuangan. Usaha yang terdapat pada perbankan syariah bergerak dalam bidang bisnis jasa keuangan yang mana walau menyandang nama syariah tapi tetap menginduk aturan yang telah ditetapkan oleh Bank Indonesia. Praktik pembiayaan secara syariah telah dipraktikkan sejak zaman Nabi Muhammad SAW dimana pada masa itu ada kegiatan peminjaman uang dalam hal usaha, jasa pengiriman uang dan penitipan harta. Kegiatan tersebut sekarang kembali diterapkan dengan tetap mengadopsi praktik nabi agar sesuai dengan ketentuan syariah.

Tata cara kerja perbankan syariah berdasarkan dua kepatuhan antara lain kepatuhan syariah dalam fatwa Dewan Syariah Nasional (SDN) dan kepatuhan operasional pada peraturan Bank Indonesia. Kedua kepatuhan tersebut dijalankan tanpa harus mengucilkan salah satu kepatuhan. Dalam bank syariah nama-nama yang digunakan dalam pendanaan dan pembiayaan banyak menggunakan istilah Bahasa Indonesia yang dikombinasikan dengan Bahasa Arab seperti giro wadiah, tabungan wadiah, tabungan mudharabah, deposit mudharabah, mudharabah, musyarakah, dan piutang murabahah (Uha: 2014).

Berdasarkan pedoman akuntansi perbankan syariah yang dikeluarkan oleh Bank Indonesia, ada delapan belas pos antara lain: kas, penempatan pada bank Indonesia, giro pada bank lain, penempatan pada bank lain, investasi pada efek (surat berharga), piutang, pembiayaan muharabah, pembiayaan musyarakah, pinjaman qardh, penyaluran dana investasi terikat, penyisihan kerugian dan pengahpusan-bukuan aktiva produktif, persediaan, tagihan dan kewajiban akseptasi, ijarah, aktiva istisna dalam penyelesaian, penyertaan pada entitas lain, aktiva tetap dan akumulasi penyusutan, dan aktiva lainnya. 
Bagian kewajiban yang harus dilaporkan perbankan syariah kepada bank Indonesia antara lain: kewajiban segera, bagi hasil yang belum dibagikan, simpanan, simpanan dari bank lain, kewajiban lain, kewajiban dana investasi terikat, hutang pajak, dan estimasi kerugian komitmen dan kontijensi, pinjaman yang diterima, dan pinjaman subordinasi. (Bank Indonesia: 2013). Akuntansi perbankan syariah mendokumentasikan jurnal keuangan yang masuk dengan pendanaan dan jurnal keuangan yang keluar disebut pembiayaan. Dengan perhitungan akuntansi yang berlandaskan syariah, para nasabah yang dulunya antipati terhadap perbankan mulai membuka diri untuk menggunakan perbankan dalam bertransaksi. Tidak menutup kemungkinan juga ada yang dulunya pengguna perbankan konvensional berpindah menjadi pengguna perbankan syariah.

\section{Kajian Pustaka}

Akuntansi bank syariah merupakan rangkaian perhitungan keuangan dari mengumpulkan hingga menyalurkan dana. Kegiatan pengumpulan dana oleh bank syariah berbeda dengan bank konvensional yang mana pada perbankan syariah menggunakan produk giro, tabungan wadi'ah, tabungan dan deposito mudharabah. Perbankan syariah memiliki tiga produk ungguulan antara lain mudharabah mudharabah, musyarakah dan jual beli murahabah (Amauludi AC: 2015). Akuntansi syariah dipraktikkan oleh perbankan syariah, dimana lembaga bisnis keuangan tersebut menerapkan ekonomi yang berabasis syariah. Visi dari perbankan syariah berbeda dengan perbankan konvensional yang menginginkan keuntungan setinggi-tingginya di perbankan syariah aspek kesejahteraan masyarakat begitu diperhatikan juga. Aspekaspek tersebut dijalankan ke dalam zakat, infaq, sedekah, hibah, dan juga waqaf (ZISW). Akuntansi perbankan syariah merupakan lembaga keuangan yang memberikan jasa dalam hal pembiayaan yang berhubungan dengan pembayaran keuangan yang berprinsip syariah (Donny: 2006).

Pertumbuhan perbankan syariah di Indonesia perlu diimbangi dengan sosialisasi operasional yang dilakukan oleh perbankan berbasis syariah, hal itu dilakukan agar para 


\section{8 | Nur Ika Mauliyah, STUDI LITERATUR: ANALISIS TEORI KONTEMPORER AKUNTANSI ....}

calon pengguna jasa dapat mengerti konsep-konsep yang ditawarkan seperti bagi hasil beserta pengaruhnya terhadap laporan keuangan (Sofyan S, dkk: 2010). Akuntansi perbankan syariah memiliki nilai dalam hal mendokumentasi, klasifikasi, merangkum, mengumumkan dan menganalisa setiap tindakan-tindakan perbankan terutama dalam hal transaksi yang tetap berisikan kandungan syariah agar bisnis keuangan terbuka bagi para pemakainya (Mauludi: 2015). Akuntansi perbankan syariah berbeda dengan akuntansi syariah dan akuntansi konvensional, hal tersebut dikarenakan kata perbankan yang menjadi obyek pebicaraan yang langsung mengarah ke bisnis jasa keungan. Perbankan sendiri harus mematuhi dua hal yaitu Dewan Syariah Nasional (DSN) dan Bank Idonesia.

Pembagian keuntungan perbankan syariah dikenal dengan bagi hasil sehingga hubungan antara perbankan dan nasabah ada aspek spiritualnya juga (Pradja: 2013). Ekonomi Islam menawarkan perekonomian yang ilmiah dan koheren terhadap perekonomian saat ini. Akuntansi konvensional yang berkembang saat ini tidak menerapkan perekonomian agama sehingga condong ke arah kapitalisme. Pertumbuhan dan pererapan industri ekonomi saat ini lebih ke aktiva berwujud sehingga memiliki akses yang terbatas dengan aktiva yang tidak terwujud seperti digitalisme yang saat ini sedang berkembang pesat. Akuntansi syariah menerapkan akad syariah yang menghindari unsur-unsur haram, zalim, riba, judi, dan penipuan (Pratama, dkk. 2017).

\section{Peranan Akuntansi Syariah}

Tahapan akuntansi memberi dampak terhadap manajemen, pemilik, pegawai, dan juga nasabah. Akuntansi saat ini dipengaruhi oleh paham kapitalisme sehingga nilainilai keIslaman dalam praktik perbankan begitu kecil. Praktik akuntansi syariah ingin menerapkan lingkungan bisnis yang menanamkan unsur-unsur agama seperti teologis, humanis, dan transendental. Akuntansi syariah menampilkan kenyataan sosial yang berdasarkan agama bukan hanya sekedar mencari keuntungan semata. Akuntansi menerapkan sistem yang mencatat dan melaporkan hal-hal yang berkaitan dengan keuangan pada sebuah perusahaan atau organisasi yang pada praktiknya telah dirancang agar bisa mengetahui transaksi keuangan yang ada di dalamnya. Perbankan syariah 
boleh saja mendapatkan keuntungan dari transaksi yang mana diperoleh melalui laba atas transaksi yang mana laba itu merupakan selisih antara biaya produksi suatu barang dengan harga yang terjual di pasaran (Wiyono dan Maulamin: 2012).

Dalam prakteknya, produk pembiayaan syariah ada 4 macam yaitu jual beli, prinsip sewa, bagi hasil dan akad yang mana ke-empat hal tersebut menghimpun keuangan di perbankan syariah dalam bentuk tabungan, giro atau deposito (A.Karim: 2004). Masalah perekonomian saat ini bukan hanya terletak pada penerapannya yang hanya konvensional kontemporer, tapi semakin kearah yang kontroversial sehingga keilmuan ekonomi ada yang kurang melengkapi kehidupan terutama di daerah yang mayoritas beragama Islam. Akar akuntansi syariah terletak pada ilmu fiqh yang mana menerapkan disiplin keilmuan pada dua sumber utama agama Islam yaitu Al-Qur'an dan Al-Hadtits (Aravik, H., \& Hamzani, 2021).

Perbankan syariah berdiri bertujuan untuk melaksanakan UU no. 21 tahun 2008, peran akuntansi adalah untuk mewujudkan tujuan-tujuan tersebut seperti wajib melaksanakan himpunan dan penyaluran dana masyarakat, pelaksanaan baitul mal, dan menghimpun dana sosial (UU no. 21 Tahun 2008). Prinsip akuntansi perbankan syariah tercantum dalam Al-Qur-an yang mana menekankan untuk muslim agar mencatat setiap transaksi penjualan dari kadar hingga waktu sehingga mudah memberikan pertanggungjawaban, adil dan juga memiliki unsur kebenaran. Manajemen akuntansi yang selama ini konvensional mampu diubah syariah sehingga memiliki unsur-unsur yang realistis dalam konsep-konsep keagamaan. Akuntansi ekonomi kapitalis yang digunakan berdasarkan keilmuan bebas nilai sehingga dasarnya rasional sesuai dengan kondisi peradaban saat itu. Konsep leporan keuangan menyesuaikan keinginan stakeholder.

Akuntansi syariah memberikan sebuah harapan dalam bertransaksi yang mana ada hak dan kewajiban antara perbankan dan nasabah yang mana menggunakan prinsipprinsip syariah yang mengharuskan untuk jujur, adil, bijak, paruh dengan value bisnis Islami, informasi laporan keuangan yang didapatkan berguna agar nasabah dapat mengambil keputusan, dan segala transaksi dan jenis usaha harus tunduk sesuai 


\section{0 | Nur Ika Mauliyah, STUDI LITERATUR: ANALISIS TEORI KONTEMPORER AKUNTANSI ....}

kebijakan syariah (Wiyono: 2012). Segala laporan akuntansi syariah tidak boleh tercatat secara konvensional karena itu melanggar ketentuan yang telah ditetapkan. Tujuan pengembangan pada akuntansi perbankan syariah yaitu mampu memberi nilai sehingga memiliki daya saing yang mampu bersaing diantara perbankan konvensional dengan tetap memegang nilai-nilai syariah sehingga mampu memberi pilihan yang lebih baik kepada masyarakat sehingga bisa memperbaiki kesejahteraan dan memenuhi standar operasional keuangan syariah yang telah ditetapkan oleh MUI dan BI (Zumaroh: 2018).

\section{Sifat dan Praktik Akuntansi Perbankan Syariah}

Perbankan syariah muncul di Indonesia memberikan alternatif lain bagi pengguna bank konvensional. Perbankan syariah menerapkan sistem bagi hasil yang mana perhitungannya berdasarkan prinsip bagi hasil terhadap laporan. Dalam berbagi keuntungan, bagi hasil lebih tetap dibandingkan dengan berbagi keuntungan yang diterapkan oleh bank konvensional. Bank syariah dan konvensional memiliki persamaan seperti teknis penerimaan uang, mekanisme transfer, teknologi, syarat umum pembiayaan, dan lainnya. Tapi jika membahas lebih dalam tentang perbedaan maka aada perbedaan mencolok antara bank konvensional dengan bank syariah terutama dalam hal bunga dan riba. Dalam penerapan akuntansi perbankan syariah tidak mengenai konsep time-value of money, tidak menggunakan dua harga untuk satu barang dan pelaporan laba rugi ditambah dengan laporan alokasi untung dan rugi kepada pemilik investasi tidak terikat dan menjadi beban atau pendapatan. Standar akuntansi yang mana dilakukan oleh akuntansi perbankan syariah memiliki peran dalam akuntansi pemilik dana dan akuntansi pengelola dana (Sofyan S, dkk: 2010).

Saat melakukan transaksi dengan menggunakan prinsip mudharabah, perbankan syariah dapat bertindak sebagai pemilik dana maupun pengelola dana. Hal tersebut dikarenakan posisi perbankan syariah memposisikan diri di aplikasi produk pembiayaan mudharabah (Sofyan S, dkk: 2010). Akuntansi perbankan syariah bersifat orientasi sosial yang mana berhubungan langsung dengan masalah ekonomi dan politik yang berperan dalam menyelaraskan kepentingan bisnis ditengah-tengah masyarakat. Perkembangan teori dan praktik akuntansi dalam Islam dikembangkan berdasarkan nilai 
egoistik, utilitarian, dan materialistik yang mengandung unsur ketauhidan sehingga mampu bersaing dalam akuntansi modern. Akuntansi perbankan syariah berusaha untuk membantu hakikat perekonomian yang mana memberikan informasi dan media dalam mengelola laporan keuangan.

Perbankan syariah sedari awal memiliki keuntungan terutama saat menampakkan diri di dunia perbankan Indonesia, dikarenakan jumlah penduduk muslim Indonesia masihlah yang terbesar di Indonesia (Antonio, dkk: 2006). Akuntansi perbankan syariah di Indonesia mengikuti dua lembaga yaitu Bank Indonesia (BI) dan fatwa Majelis Ulama Indonesia (MUI) dalam melaksanakan kegiatannya. Gagasan yang diterima dilaksanakan dengan menyeluruh dan obyektif. Memang pada awal praktiknya mengalami beberapa kendala tetapi saat ini akuntansi berbasis syariah telah diterima oleh masyarakat bukan hanya di Indonesia tetapi di beberapa negara di dunia juga menerimanya. Akuntansi perbankan syariah memiliki sikap pertanggungjawaban, keadilan, dan kebenaran yang tinggi karena menerapakan implementasi keagamaan didalamnya terutama dalam segi pelaporan.

Tantangan untuk akuntansi perbankan syariah terdapat pada kondisi makroekonomi yang mana harus mengambil langkah yang tepat karena perbankan syariah masihlah mengerjakan sektor terbatas, SDM yang kurang, menarik minat masyarakat tentang pembiayaan syariah, dan penyesuaian kebijakan dengan pemerintah (Zumaroh: 2018). Pembiayaan murabahah yang dipraktikkan oleh perbankan syariah mengharuskan perbankan untuk menyediakan barang sesuai keinginan nasabah (pembeli) atau langsung melakukan pembelian barang. Pembiayaan ini memerlukan analisis yang lebih dalam dibandingkan akuntansi konvensional agar pihak perbankan tidak keliru memilih nasabah dalam memberikan dananya. Sehingga dalam praktiknya risiko pembiayaan berkurang karena sedari awal sudah protektif dalam memberi bantuan ke nasabah yang masuk masuk ke dalam kategori kurang lancar, macet atau tidak memenuhi kewajiban (Karim: 2004). Pembiayaan yang ditawarkan oleh sistem syariah berbeda dengan kosep konvensional pada jual beli yang lebih menekankan 


\section{2 | Nur Ika Mauliyah, STUDI LITERATUR: ANALISIS TEORI KONTEMPORER AKUNTANSI ....}

kepada lada atau keuntungan dalam perkembangan dan pertambahan nilai barang sehingga pada praktiknya laba tidak bisa dibagi jika laba itu diperoleh dahulu.

\section{Simpulan}

Berdasarkan studi litelatur yang telah diungkapkan diatas maka dapat disimpulkan beberapa perspekti akuntansi perbankan syariah yang dalam kegiatannya menerapkan sistem yang berdasarkan unsur keagamaan yang mana dalam praktiknya tidak hanya bertujuan untuk mendapatkan keuntungan semata tapi juga humanis dan dalam pelaporan keuangannya tidak ada unsur kebohongan yang mana akan merugikan pihak tertentu dan juga perusahaan. Akuntansi perbankan syariah hadir untuk memenuhi kebutuhan akuntansi masyarakat yang menginginkan adanya unsur keagamaan dalam praktiknya. Ilmu akuntansi itu sendiri sangatlah luas dan memiliki beberapa macam. Setiap perusahaan atau organisasi yang mau menjalankan sistem yang Islami tentu akan menerapkan akuntansi syariah dalam pelaporan kegiatannya.

Di masa sekarang ini, akuntansi perbankan syariah memiliki peran dalam mewujudkan laporan-laporan keuangan yang dikelola oleh perbankan dan melaporkannya kepada para pengguna agar mereka dapat menentukan tindakan yang akan diambil selanjutnya. Perbankan lembaga keuangan syariah tumbuh semakin subur dan itu harus diimbangi dengan akuntansi yang mengarahkan masyarakat untuk melihat prospek keuntungan dengan berinvestasi di perbankan syariah. 


\section{DAFTAR PUSTAKA}

A. Karim, Adiwarman. (2004). Bank Islam Analisis Fiqih dan Keuangan. Jakarta: Raja Grafindo Persada.

Antonio, M. Syafi'i, dkk, (2006). Bank Syari'ah Analissi Kekuatan, Kelemahan, Peluang, dan Ancaman. Yogyakarta. Ekonisia.

Aravik, H., \& Hamzani, A. (2021). Etika Perbankan Syariah: Teori dan Implementasi. Deepublish.

Uha, Ismail Nawawi. (2014). Manajemen Perbankan Syariah. Jakarta: VIV Press.

Mauludi AC, Ali. (2015). Akuntansi Perbankan Syariah (Sebuah Kajian Teori dan Praktik Kontemporer). Jurnal Iqtishadia Ekonomi Islam IAIN Tulungagung, Volume 2.

Bank Indonesia. (2013). Pedoman Akuntansi Perbankan Syariah Indonesia. Jakarta.

Pradja, Suhaya S. (2013). Manajemen Perbankan Syariah. Bandung: Pustaka Setia.

Pratama, Bima Cinintya, dkk. (2017). Penerapan Praktik dan Teori Akuntansi Syariah Berdasarkan Prinsip Syariah, Akusisi II Journal of Accounting \& Finance, Volume 13 Number 2, Page 83-91, 2017.

Donny, Duddy Roesmara. (2006). Variabel-Variabel yang Mempengaruhi Pembiayaan Perbankan Syariah di Indonesia. Yogyakarta: FE UGM.

Sofyan S, Harahap, Wiroso, Muhammad Yusuf. (2010). Akuntansi Perbankan Syariah. Jakarta: PT Sardo Sarana Media.

Wiyono, Slamet dan Maulamin. (2012). Memahami Akuntansi Syariah di Indonesia. Jakarta: Mitra Wacana Media.

Zumaroh. (2018). Prospek Pengelolaan Keuangan Bank Syariah di Indonesia. Finansia: Jurnal Akuntansi dan Perbankan Syariah, Volume 01, Nomor 02. 
344 | Nur Ika Mauliyah, STUDI LITERATUR: ANALISIS TEORI KONTEMPORER AKUNTANSI .... 